\title{
CAMA
}

Centre for Applied Macroeconomic Analysis

\section{Modelling the Economic Impacts of Korean Unification}

\section{CAMA Working Paper 30/2017 April 2017}

Warwick J. McKibbin

Crawford School of Public Policy, ANU

The Brookings Institution, Washington DC and

Centre for Applied Macroeconomic Analysis, ANU

Jong Wha Lee

Korea University and

Centre for Applied Macroeconomic Analysis, ANU

Weifeng Liu

Crawford School of Public Policy, ANU and

Centre for Applied Macroeconomic Analysis, ANU

Cheol Jong Song

Korea University

\section{Abstract}

This paper explores the economic impacts of Korean unification on North and South Korea. It presents a new consistent database on macroeconomic, sectoral and trade data, and an input output table for the North Korean economy, and then incorporates it in a global intertemporal multi-sector general equilibrium model. Assuming three hypothetical scenarios such as North Korea's reform and gradual convergence, its sudden collapse and immediate unification, and chaos and crises in both Koreas, we quantify the consequences of Korean unification on economic activity, trade and capital flows in the two Koreas. The results highlight the importance of the unification processes and of alternative policy responses in both Koreas to the economic impacts of unification. 


\section{Keywords}

Korean unification, North Korea, economic integration, dynamic general equilibrium, economic growth, convergence

\section{JEL Classification}

$\mathrm{F} 15, \mathrm{H} 77, \mathrm{O} 19, \mathrm{O} 23, \mathrm{O} 53$

\section{Address for correspondence:}

(E) cama.admin@anu.edu.au

ISSN 2206-0332

The Centre for Applied Macroeconomic Analysis in the Crawford School of Public Policy has been established to build strong links between professional macroeconomists. It provides a forum for quality macroeconomic research and discussion of policy issues between academia, government and the private sector.

The Crawford School of Public Policy is the Australian National University's public policy school, serving and influencing Australia, Asia and the Pacific through advanced policy research, graduate and executive education, and policy impact. 


\title{
Modelling the Economic Impacts of Korean Unification
}

\author{
Warwick J. McKibbin \\ CAMA, Crawford School of Public Policy, ANU \\ $\&$ The Brookings Institution, Washington DC \\ Jong Wha Lee \\ Korea University \\ Weifeng Liu \\ CAMA, Crawford School of Public Policy, ANU \\ and \\ Cheol Jong Song \\ Korea University
}

April 2017

The authors thank Michael Burda, Marcus Noland, Rod Tyers and participants at the workshops at the Australian National University, the Bank of Korea, the Brookings Institution, and Korea University for useful comments and suggestions. This research is funded by a grant from the Australian Research Council \# DP150103821. 


\title{
Modelling the Economic Impacts of Korean Unification
}

\begin{abstract}
This paper explores the economic impacts of Korean unification on North and South Korea. It presents a new consistent database on macroeconomic, sectoral and trade data, and an input output table for the North Korean economy, and then incorporates it in a global intertemporal multi-sector general equilibrium model. Assuming three hypothetical scenarios such as North Korea's reform and gradual convergence, its sudden collapse and immediate unification, and chaos and crises in both Koreas, we quantify the consequences of Korean unification on economic activity, trade and capital flows in the two Koreas. The results highlight the importance of the unification processes and of alternative policy responses in both Koreas to the economic impacts of unification.
\end{abstract}

JEL Code: F15, H77, O19, O23, O53

Keywords: Korean unification; North Korea; economic integration; dynamic general equilibrium; economic growth; convergence 


\section{Introduction}

There is significant uncertainty and concern about the current situation and prospects in the Korean peninsula. Amid its economic hardship, North Korea launched its nuclear weapons programs and is highly unlikely to denuclearize, at least in the immediate future, despite harsh sanctions by the United States and the United Nations. Looking into the economic and political future of North Korea is highly speculative at this moment. In the immediate future, no one would expect any significant change in North Korea. The North Korean leaders will likely continue current policies, obstinately avoiding domestic reforms and developing nuclear weapons and long-range missiles. Although it is a slim possibility, however, North Korea could adopt serious market reforms and opening, which may lead to gradual and peaceful unification. On the other hand, the North Korean regime may succumb to collapse but it is hard to predict when and how this collapse will happen. No one expected the fall of the Berlin Wall and the German reunification or the end of the Vietnam War and the sudden unification of North and South Vietnam until they happened.

This study aims at quantitatively assessing the impacts of Korean unification on North and South Korea and the rest of the world under three hypothetical scenarios, such as 1) North Korea's reform and gradual convergence, 2) North Korea's sudden collapse and immediate unification, and 3) chaos and crises in North and South Korea. Regardless of the scenarios, Korean unification would have far-reaching political, economic and strategic consequences not only in the two Koreas but in neighboring economies in Asia and the Pacific.

There are many studies suggesting various views on the future of North Korea and consequences of Korean unification. One major branch of the literature constructs general equilibrium models for North Korea to simulate unification scenarios. ${ }^{1}$ Noland, Robinson and Wang (2000) use a computable general equilibrium model to analyze economic integration between North and South Korea. They show that product market integration generates large welfare gains for North Korea, in contrast to only a trivial gain for South Korea. Bradford and Phillips (2005) and Bradford, Kim and Phillips (2011) construct a

\footnotetext{
${ }^{1}$ Lee and McKibbin (2017) provide a complete review of the literature on estimating the economic impacts of Korean unification from the economic perspective.
} 
dynamic general equilibrium model to examine the impacts of economic reform and unification of North and South Korea. Their results suggest that the gains for North Korea in all scenarios are dramatic in the short run as well as in the long run. Funke and Strulik (2005) construct a two-region endogenous growth model in which the productivity is determined by productive public capital. They argue that with fiscal transfer from South to North Korea, the productivity level of North Korea can increase quickly, reducing its gap with that of South Korea. St. Brown, Choi and Kim (2012) also build a growth model of productivity catch-up, and show that the economic consequences of unification hinge critically on speed of productivity convergence, labor migration from North to South Korea, and capital flows from South to North Korea to South Korea.

This study contributes to this line of literature with a particular focus on the linkages between the North Korean and South Korea economies and the world economy and the dynamics of adjustment to economic reform and unification, in various unification scenarios. We construct a new consistent database of macroeconomic, sectoral and trade data including an input-output table - for the North Korean economy. It is then combined with South Korea and other economies in the world using the G-Cubed model of the world economy, which is a global dynamic stochastic general equilibrium model. The G-Cubed model considers an inter-industry input-output structure, factor movements and dynamics of consumption and investment (McKibbin and Wilcoxen, 2013). The model also incorporates spillovers across the border through trade and financial linkages. Using this model, we explore what would happen in the two Koreas if Korean unification occurs. Assuming three different scenarios, this paper quantifies the consequences of Korean unification on economic activity, trade and capital flows in the two Koreas.

Use of a dynamic multi-sector global economy model in this paper where a new database for the North Korean economy is incorporated contributes to the literature in several aspects. First, it helps to analyze more thoroughly the process and impact of Korean economic integration and unification. Whether the unification would be gradual or sudden will have different economic impacts on South and North Korean economies. When the unification process is gradual along an anticipated path, for example, South Korea will have more time to construct better policies and more financial resources to reduce the unification costs and to mitigate the adverse effects of unification. On the other hand, a military conflict or political risk in North Korea is likely to augment the fiscal burden of South Korea and the uncertainty 
and risk in the Korean peninsula and Northeast Asia. Our approach allows assessing the impacts of these different scenarios on trade and investment relations among North Korea, South Korea, and the neighbors such as China and Japan.

Second, by building a new macroeconomic and sectoral database including a 6-sector input-output table for North Korea, the paper allows analysis of the impacts of sectoral productivity changes and inter-industry resource allocation in North Korea under different unification scenarios. The productivity levels and growth rates vary across sectors in North Korea. If North Korea adopts serious market reform and opening, it would have more trade and financial transactions with South Korea and the rest of the world. The patterns of structural change and economic growth of the North Korean economy will depend on its natural comparative advantage but also the sectoral adjustment to international integration. In addition, an industrial policy which aims to promote mining or manufacturing industries with comparative advantage can be an option for North Korea during the process of reform and unification. The multi-sector analysis using the input-output table enables exploration of the impact of industrial policy.

There are many other issues that the research in this paper can be used to explore: the role of different policies and institutions on short-run adjustment; the role of different exchange rate regimes, fiscal institutions, monetary and wage policies of North and South Korea during the unification process. While this paper focuses on analyzing the effects of the different unification scenarios on both Koreas, the unification process will have significant spillovers to the neighboring economies in Asia and the Pacific. These will be the focus of a series of future papers.

The organization of this paper is as follows. Section 2 describes the North Korean economy and constructs the new input-output table for North Korea. Section 3 shows our simulation of the effects of the unification, including the model, scenarios and simulation results. We conclude in Section 4.

\section{Growth and structural change of North Korean economy}

In this section, we describe the North Korean economy from the perspectives of economic growth, trade openness, economic policy, and industrial structure, in comparison with South 
Korea. We then illustrate how we construct a new Input-Output (IO) table for North Korea in 2014.

\subsection{Economic growth, trade openness and industrial structure}

Since the political division of the Korean peninsula in 1948, North Korea adopted a centrally planned economic system, while South Korea followed a market-based system. The two different roads lead to an enormous disparity of the two economies after about half a century. In the 1950s North Korea had a similar level of GDP per capita to South Korea, but their gap has been remarkably widened over time. The Bank of Korea estimates that North Korea's per capita income, at USD 1,200, is less than 5\% of South Korea's in 2015.

This wide divergence was attributed not only to the rapid growth of the South Korean economy but also to the stagnation and crisis in the North Korean economy. It is estimated that the North Korean economy nearly halved in the 1990s due to both domestic and external changes (see Figure 1). The external economic assistance from the former Soviet Union and China was important for the North Korean economy. The collapse of the Soviet Union and China's demand for trade settlement in hard currency significantly undermined the North Korean economy. On the domestic side, North Korea suffered a series of natural disasters in the mid-1990s but maintained its defense spending as high as about $25 \%$ of its GDP (Wolf and Akramov 2005). All these adverse factors contributed to a severe contraction in the economy given its rigid economic system. The Bank of Korea estimates that the aggregate economy of North Korea shrank at an annual rate of $-0.5 \%$ over the period of $1990-2014$. The economy performed very badly in the 1990s with average GDP growth rate of $-4.6 \%$ in 1990-1995 and -1.0\% in 1995-2000. The North Korean economy performed better after 2000. It grew at an annual rate of $1.3 \%$ over the 2000 s and $1.1 \%$ over $2010-2014$.

At the sectoral level, the agriculture and government sectors are the two largest sectors of North Korea. Agriculture accounts for $20-30 \%$ of GDP, and government services for $20-25 \%$ of GDP since the 2000s (see Figure.2). In 2014, services amounted to $31.3 \%$ of the whole economy. Government services $(22.7 \%)$ was much larger than other market services $(8.6 \%)$. Agriculture, forestry and fishing and manufacturing had the similar shares in aggregate nominal GDP, $21.8 \%$ and $21.3 \%$ respectively.

At the initial stage after the Korean War, North Korea followed the Soviet Union model 
with the ideology of self-reliance, and its economic development was dominated by industrialization, especially in heavy industry. The share of heavy manufacturing was above $25 \%$ in 1990 and thereafter declined sharply since the economic trouble started in the early 1990s. While the agriculture and service sectors slightly grew, all other sectors contracted over the period of 1990-2014 (see Lee and McKibbin, 2017). In particular, the heavy manufacturing industries contracted with an average growth rate of $-8.5 \%$ per year over 1990s.

Table 1 contains the number of workers by industry and employment share of each industry of North Korea in $2008 .^{2}$ Agriculture had the biggest share in employment amounting to $36 \%$ of total workers. The share of service sector $(29.7 \%)$ in employment was larger than that of manufacturing (23.7\%). With respect to the sectoral shares in employment, the economic structure of North Korea in 2008 was similar to that of South Korea in the late 1970s. In 1978, the employment shares of agriculture, manufacturing and services of South Korean were $38.4 \%, 22.3 \%$ and $38.5 \%$ respectively.

In 2008, the aggregate labor productivity of North Korea was 2.49 million won per worker. The labor productivity of agriculture was quite low at 1.46 million won in 2008 even though the share of agriculture in employment was the highest. Another sector which had a high employment share but low labor productivity was manufacturing. Its employment share was $23.7 \%$ but its labor productivity was 2.35 million won. However, in manufacturing, the labor productivity of heavy industry was 3.04 million won which was higher than the aggregate labor productivity. The service sector had similar labor productivity to the aggregate economy, but it was mainly driven by the government services. In the North Korean economy, mining, electricity, gas and water supply and construction had higher labor productivities than other sectors.

For comparison, Table 2 provides the sectoral labor productivity of South Korea in 2008, and the ratio of sectoral labor productivity between South and North Korea. In 2008 the aggregate labor productivity of South Korea was 45.2 million won which was about 18 times larger than North Korea. The labor productivities of all sectors of South Korea were much

\footnotetext{
2 The number of workers over age 16 by economic activities in North Korea comes from North Korea Statistics of Korea National Statistical Office in South Korea. The data is originally constructed by the United Nations Population Funds (UNFPA). North Korea conducted population census with the assistance of UNFPA in 1993 and 2008 .
} 
larger than those of North Korea, ranging from 5.1 times in construction to 33.4 times in manufacturing.

The North Korean economy is one of the most internationally isolated economies in the world, with very limited trade with a small number of trading partners. South Korean trade was about 30 times more than that in North Korea in 1990 and this ratio exploded to more than 150 times in 2015. North Korea experienced a notable decline in international trade in the 1990s due to the collapse of the Soviet Union and the reduction of Chinese exports to North Korea, but this recovered in the 2000s, especially in the late 2000s (see Fig.3), with much of the export growth being with China. China and South Korea dominate the small group of North Korea's trading partners, accounting for more than $90 \%$ of its international trade in 2015. Mining, and fabrics and wood in the non-durable manufacturing sector are the major exporting sectors while metal, electronics and plastics in the manufacturing sector are the major importing sectors. Trade between North Korea and South Korea increased markedly in the late 1990s when South Korea's Sunshine Policy warmed up their relationship (see Figure 4).

North Korea has kept the centrally planned socialist command system while other socialist countries have followed a process of marketization to reduce the inefficiency in their economies. In North Korea, there has been some expansion of the private market since the centrally planned command system failed to overcome the food crisis in the 1990s.. Thus there exists a dual economic system in North Korea, which has a centrally planned official part as well as a marketized private part of the economy. According to Choi (2016), the informal (marketized) economy is estimated to constitute about $28.5 \%$ in the final demand of North Korea.

To maintain the centrally planned economy the North Korean government budget was large until the 1980s. During the economic crisis in the 1990s North Korea suffered from severe budget deficits, and it tried to reduce the fiscal expenditure. According to the estimates by the U.S. Department of State (2015), the military expenditures of North Korea amounted to $22 \%$ of GDP in 2012, contrasting to only $2.7 \%$ of GDP in South Korea.

Since North Korea is a centrally planned economy, all economic decisions such as prices, interest rates, production, investment and financing are made by the government, so the 
monetary policy that aims at economic growth or price stabilization is not required at all. ${ }^{3}$ But the government uses "the currency control work", which eliminates the discordance of money in the economy through the central bank adjusting money supply, to facilitate the currency circulation of and to stabilize the currency value.

The exchange rate of North Korea is also controlled by the government. There are three types of exchange rates: the official exchange rate; the trade exchange rate; and the non-trade exchange rate. The official exchange rate is used when the aggregate economic indicators are converted into foreign currencies. The non-trade exchange rate is applied to money exchange and financial transaction of tourists. The trade exchange rate is used in international trade settlement. It is frequently adjusted by the government and represents the exchange rate of North Korea. In addition, there is an exchange rate in the black market. Since the economic reforms in July 2002, the government devaluated the official exchange rate with the market exchange rate as the benchmark, from 2.2 to 152.5 Won per US dollar. After this devaluation, the official exchange rate is relatively stable while the market exchange rate continues to devaluate, with the market exchange rate about 20 times of the official exchange rate in the past decade (Lee, 2012).

\subsection{Input-Output table}

An IO table is an economic tool that systemically and completely presents the sales and purchases relationships between sectors in a country for a specific time period following specific rules and formats. In this section we introduce IO tables that have been constructed by previous studies and then construct a new IO table of North Korea for year 2014.

Choi (2014) establishes North Korea's IO table for 2011. The IO table divides the North Korean economy into 7 industries matched to the industry classification of Economic Statistics System of Bank of Korea. Shin (2009) constructs an IO table of North Korea for 2009 with 11 industries. Both Choi (2014) and Shin (2009) apply the cross entropy minimization method to estimate North Korean IO tables. To use the cross entropy minimization (Robinson, Cattaneo and El-Said, 1998), the benchmark IO coefficient matrix is required. Choi (2014) uses Vietnam's 2000 input coefficient matrix assuming that the North

\footnotetext{
${ }^{3}$ For the details of the monetary policy, the central bank and the exchange rate policy in North Korea, refer to Lee (2012) and Cho (2015)..
} 
Korean economy in 2011 was similar to the Vietnamese economy in 2000. On the other hand, Shin (2009) uses East Germany's input coefficient matrix, assuming that the North Korean economy in 2007 was similar to East Germany around unification time.

\section{a. Estimation of a new IO table}

We use the cross entropy minimization method, to construct a new North Korean input coefficient matrix that is not only close to the benchmark input coefficient matrix by minimizing a cross entropy of the difference between the new and the benchmark matrix, but also satisfies all constraints imposed by the IO table.

Because of the scarcity of North Korean data, all previous studies assume that the IO structures under the centrally planned systems are similar, and then use the IO tables of other former socialist countries for North Korea. Shin (2009) estimates a North Korea 2007 IO table using East German IO table around the unification time as a benchmark coefficient matrix. But the current North Korean economy is clearly different from the East German economy around unification time. Around the time of unification East Germany was much more developed than North Korea nowadays. Compared to North Korea in 2014, East Germany in 1991 had a much smaller agriculture sector and a much bigger service sector.

Choi (2014) uses Vietnam's 2000 I/O table as a benchmark input coefficient matrix to estimate North Korea's 2011 IO table, and also uses other information including North Korea's sectoral output, export and import in 2011. We also use a Vietnamese IO table as the benchmark information but assume that the current North Korean economy is more similar to the Vietnamese economy in 2011 than in 2000. Per capita income of North Korea in 2014 was more similar to that of Vietnam in 2011 than in 2000. Table 3 shows that the industrial structure of Vietnam in 2011 was similar to that of North Korea in 2014. Therefore, it is more reasonable to use the Vietnam 2011 IO table as the benchmark rather than the Vietnam 2000 IO table. We use the IO table for Vietnam in 2011 collected from the OECD STAN database as prior information for the North Korean IO table.

Choi (2016) uses the South Korean IO table in 1975 as prior information to estimate North Korean IO table, assuming that the main features of the input output structure of North Korean economy are close to those of South Korean economy in the 1970s. But this assumption is not well justified because South Korea had rapidly grown since the 1960s under the market economy. According to World Bank data, the shares of agriculture, 
manufacturing and services in South Korean GDP were, on average, 24\%, 19\% and 47\% respectively in the 1970s. Thus, the industrial structure of North Korea in 2014 is more similar to Vietnam in 2011 than South Korea in 1970. In addition, between Vietnam and North Korea we observe the similarity in the industrial share in total trade as well (Table 4). In North Korea in 2014, agriculture was almost $10 \%$ and manufacturing was about $65 \%$ in total trade. The shares of agriculture and manufacturing in Vietnamese 2011 trade were 5\% and $68 \%$. In contrast, those shares in South Korean trade in 1970 were $22 \%$ and $65 \%$. In 1970 South Korea had a much bigger trade share in agriculture than the current North Korea. We judge that it is a reasonable assumption to use Vietnamese economy as a benchmark for North Korea.

ECOS of the Bank of Korea reports North Korea's sectoral GDP up to 2015. We can get North Korea's sectoral export and import data up to 2014 from Korea Trade-Investment Promotion Agency (KOTRA) and North Korea's government budget size up to 2014 from KOSIS (Korean Statistical Information Service). ECOS of Bank of Korea reports North Korean nominal and real GDP by sectors in South Korean Won. We calculate the total sectoral output for North Korea by dividing the North Korean sectoral GDP by the Vietnamese sectoral value-added coefficients.

Since data for consumption, investment and government expenditure of North Korea is not available, we need to make some assumptions about them. We use data for the government budget size of North Korea as a proxy for the government expenditure. We borrow the shares of consumption and investment in GDP of the Vietnamese economy in 2011 for North Korea. We also use the sectoral shares of consumption, investment and government expenditures of Vietnam in 2011 for North Korea, but adjust those shares to satisfy the constraint that the aggregate value added is equal to the total expenditure of national income.

\section{b. Results of North Korean new IO table}

As mentioned before, to apply the cross entropy minimization method, we use the Vietnamese input coefficient matrix for 2011 as prior information. In this matrix, the sectoral shares of the intermediate demand, export and import come from the OECD STAN database and the data of the remaining exogenous part come from GTAP 9 because the IO table in OECD STAN database does not report government expenditure. The cross entropy 
minimization method produces a new input coefficient matrix for North Korea (Table 5). Table 6 shows the new IO table of North Korea in 2014 that we construct by using the new input coefficient matrix and all sectoral output and aggregate data for the exogenous part. ${ }^{4}$

Table 5 shows that about $92 \%$ of the government expenditure is used for the final demand for the service sector. Since the service sector contains government services, it implies that the government expenditure for government services takes most of the final demand for government services. When we divide services into government services and other services, government expenditure for government services is about $90 \%$ of the total government expenditure. This implies that the government purchases almost all the final services produced by the government using other sectors' inputs, labor and capital, so we reallocate the final demand for government services across the other sectors, labor compensation and capital compensation. After the reallocation of government services, the shares of durable manufacturing, nondurable manufacturing and services in final demand of the government expenditure $(\mathrm{G})$ are 14\%, 12\% and 14\% respectively. The shares of each other three sectors are less than 5\%. In the final demand of the government expenditure, the labor share is $31 \%$ and the capital share is $23 \%{ }^{5}$

\section{Simulation of the Consequences of Unification}

We incorporate North Korea into the G-Cubed model, which is an intertemporal general equilibrium model of the world economy. The main features of the G-Cubed model are outlined in McKibbin and Wilcoxen (2013). A number of studies have used the G-Cubed model (or its precursor the McKibbin-Sachs Global Model) to assess a range of issues

\footnotetext{
${ }^{4}$ When the new input coefficient matrix of North Korea 2014 in Table 4 is compared with the Vietnamese 2011 input matrix, the input structure of North Korea is similar to that of the Vietnamese economy, but North Korea uses less energy input and services input than Vietnam in producing the durable manufacturing goods. In the exogenous part, the shares of the energy, mining and agriculture sectors in private consumption (C), investment (I), and total exports (X) of North Korea have larger shares than those of Vietnam in 2011.

${ }^{5}$ Considering that most government services such as defense, education and public administration are produced and supplied by labor, we assume that expenditure on labor takes the biggest share in government expenditure. However, it may not be easy to estimate the reasonable shares because of the lack of the reliable data. Some articles report the wage in government sector is lower than that in mining and manufacturing sectors. Since the North Korean government has underestimated the military expenditure, wage cost for military might be underestimated too. There is a possibility that the labor share, $31 \%$, may be underestimated.
} 
including German unification in the early 1990s (McKibbin 1990, Gagnon, Masson and McKibbin 1996).

\subsection{The Model}

The model is based on a combination of explicit intertemporal optimization by the agents (consumers and firms) in each economy and rule of thumb behavior. In contrast to static computable general equilibrium (CGE) models, time and dynamics are of fundamental importance in the G-Cubed model. The G-Cubed model is known as a DSGE (dynamic stochastic general equilibrium) model in the macroeconomics literature and as an intertemporal general equilibrium (IGE) model in the CGE literature. The main difference from the small-scale DSGE models now popular at central banks is the large amount of sectoral disaggregation and considerable degree of economy disaggregation.

In order to replicate the macro time series, the behavior of agents is modified to allow for short-run deviations from optimal behavior either due to myopia or to restrictions on the ability of households and firms to borrow at the risk-free bond rate on government debt. Thus, aggregate consumption is a weighted average of consumption based on wealth (current asset valuation and expected future after-tax labor income) and consumption based on current disposable income. Once the level of overall consumption has been determined, spending is allocated among goods and services according to a two-tier constant elasticity of substitution (CES) utility function. Similarly, aggregate investment is a weighted average of investment based on Tobin's Q (a market valuation of the expected future change in the marginal product of capital relative to the cost) and investment based on a backward looking version of Q. The model allows for short-run nominal wage rigidity (by different degrees in different economies) and, therefore, allows for significant periods of unemployment depending on the labor market institutions in each economy. Equilibrium between aggregate demand and aggregate output is maintained by flexible prices, which causes demand to adjust together with short term supply. There is explicit treatment of the holding of financial assets, including money.

Global accounting identities are imposed on the model so, for example, for every borrower there is a lender. Likewise, the model gives a careful treatment of stock-flow relations, such as the accumulation of current account deficits into foreign claims on domestic output, which has to be serviced by future trade surpluses. On the fiscal side, the accumulation of fiscal deficits into government debt has to be serviced from future 
revenues - though it does not have to be completely paid off.

The model distinguishes between the stickiness of physical capital within sectors and within economies, and the flexibility of financial capital, which immediately flows to where expected returns are highest. This important distinction leads to a critical difference between the quantity of physical capital that is available at any time to produce goods and services, and the valuation of that capital as a result of decisions about the allocation of financial capital.

The G-Cubed model embodies a wide range of assumptions about individual behavior and empirical regularities in a general equilibrium framework. The interdependencies are solved out using a computer algorithm that solves for the rational expectations equilibrium of the global economy. In the version of the model used here there are 12 economies and regions as set out in Table 12. Each economy has six sectors (energy, mining, agriculture, manufacturing durables, manufacturing non-durables, and services) as well as a generic capital-producing sector in each economy that draws largely on the durable manufacturing sector for inputs.

Applying this modeling framework to a country like North Korea under various scenarios requires a number of choices to be made. An economic model is made up of a number of key parts. The first is data. The section above describes the database that has been constructed for this project. The second is the identities of the model, both static and intertemporal. It is assumed that these hold in each country, including in North Korea. The third is how to model the decisions of households, firms and governments and how each agent interacts within markets for inputs and outputs. This latter choice is obviously problematic for a country like North Korea. The choice we make is to model North Korea as if there are shadow markets determining shadow prices and agents make decisions based on these shadow prices. The results of this study clearly depend on the data which is extremely unreliable and the modeling assumptions which are highly speculative. We acknowledge this problem but point to the valuable insights from the early modelling papers on German Unification summarized in Gagnon, Masson and McKibbin (1996), which made similar assumption about East Germany. The argument is that the specific details of a scenario will be affected by the model assumptions but the big picture results largely driven by the identities and assumptions of scenario design will be useful for understanding some of the major issues in Korean unification. 


\subsection{Unification Scenarios}

There are clearly a very large number of alternative scenarios that the model developed in this paper could be used to analyze. We choose to present some illustrative scenarios in order to understand a number of major issues.

\section{a. Status Quo}

The first scenario is our "status quo" scenario. In this case there is no collapse of North Korea. Existing barriers to the flows of people and capital into and out of North Korea are maintained. There is slow technological change of $0.5 \%$ per year in North Korea and the main driver of growth is the supply of labor generated from the UN mid-term fertility population projections and capital investment by the public and private sector.

Average GDP growth rate maintains about $1.0 \%$ for the initial period, but declines over time as population growth rate declines. There is a central bank in North Korea managing inflation and unemployment and a fiscal authority setting spending targets and raising revenue from taxing companies and households.

\section{b. Reform and Gradual Convergence}

This is the case where North Korea follows a similar path to China in gradually opening to the world economy through market-oriented economic reform. This process can be accompanied by gradual unification between two Koreas. Although this may seem highly unlikely, it does provide a benchmark for what might be possible in North Korea given initial conditions in 2017 and given the empirical evidence from other countries entering the global economy after a period of isolation. We call this scenario "reform and gradual convergence". The convergence (or conditional convergence) theory indicates that when other conditions are controlled, a country with a low level of initial per-capita output will have a higher growth rate than a country that has a higher level of per-capita output. A country with a significant gap with its potential per-capita output would be able to begin a rapid "catching up" process through high rates of physical and human capital accumulation, owing to higher rates of return to investment and technology diffusion and imitation from more technologically advanced economies. 
The assumption is that given initial gaps between labor productivity of each sector in North Korea to the equivalent sector in the United States, reform increases the rate of catchup from 0 in 2017 rising by $0.1 \%$ per year in 2018 and 2019 and then $0.05 \%$ per year until the catchup rate reaches $2.0 \%$ by 2055 . That is, the labor productivity gap between North Korea and the United State closes by $2 \%$ per year after 2055. ${ }^{6}$ The gap in the level of productivity will still be very large but the rate of growth of productivity will be high enough to close the gap by $2 \%$ per year. This is the empirical "Barro Catchup Rate". The $2 \%$ catchup rate in 2055 indicates that North Korea can adopt the policies and reforms over many years that can gradually improve its steady-state potential level of productivity to that of the United States.

We assume that this gradual reform scenario can be combined with the integration and cooperation between North and South Korea, which may accompany peaceful unification. Specifically, South Korea can provide North Korea with substantial financial aid. We assume there are fiscal transfers from South Korea to North Korea of $1.5 \%$ of South Korea's GDP or $60 \%$ of North Korea's initial level of GDP every year. These are gradually phased in at $25 \%$ (i.e. $15 \%$ of North Korea's GDP) in 2017, 50\% in 2018, 75\% in 2019 and then fully implemented from 2020. This amounts to almost the double of the German Unification case, where the transfers were $40 \%$ of East German GDP although it is only a half of $4 \%$ of West German GDP. The transfers are ended in 2043 (25 years later). We assume that of this transfer the proportion used to support private consumption is 0.5 in 2017 and rising by 0.1 per year to be the entire transfer by 2022 . The remainder of the transfer goes to government spending in North Korea.

\section{c. Managed Chaos in North Korea}

In the third scenario, we assume that North Korea collapses and there is immediate unification between North and South. The details matter for this scenario and there are many different assumptions that could be made and explored. In particular, we assume:

i) As the economy collapses, $20 \%$ of physical capital stock in all North Korea sectors becomes obsolete immediately in 2017. Labor productivity also falls by $20 \%$ in 2017.

\footnotetext{
6 Previous studies, such as Funke and Strulik (2005) and St. Brown, Choi, and Kim (2012), assume faster speed of convergence of North Korea's productivity to South Korea's when two Koreas integrate. They assume significantly larger capital transfers from North Korea to South Korea or technology transfer.
} 
Although arbitrary in size this generates approximately the collapse in the value of capital in East Germany once the Berlin wall had fallen.

ii) There are larger fiscal transfers from South Korea to North Korea compared to the convergence scenario. These are $0.5 \%$ of South Korea's GDP in 2017, 1\% in 2018, $1.5 \%$ in 2019 and 2\% in 2020. These are 20\% of North Korea's initial GDP in 2017, $40 \%$ in $2018,60 \%$ in 2019 and $80 \%$ from 2020 .

iii) There are migrants moving from North to South Korea every year equal to $0.5 \%$ of the North Korean population or $0.25 \%$ of South Korea's population. This is scaled to the East German case. The migration occurs for 15 years and then stops.

iv) Economic reforms begin to be implemented and the convergence process starts slowly in the first few years but thereafter accelerates at a faster pace than in the gradual convergence. We assume that the catchup rate rises from .2\% in 2017 to $.4 \%$ in 2018 and by .2\% per year until the Barro rate of $2 \%$ per year is reached in 2026 .

It is important to note that although unification occurs, we keep the monetary and fiscal authorities separate in the two economies and manage the flow of capital and labor between North and South Korea. Thus it is not a full unification scenario across all institutions.

\section{d. Chaos in North Korea and Crisis of Confidence in South Korea}

The final scenario is a modification of the Chaos scenario. The reform process in North Korea is delayed by 5 years (i.e. reforms begin in 2022, 5 years after the collapse). In addition there is a loss of confidence in the ability of the South Korea government to manage the unification. This is modelled as a sharp jump in the country risk premium of South Korea of 1000 basis points (10 percentage points) in 2017 followed by a gradual decline by 100 basis points per year to zero by 2027. The initial jump is of a similar magnitude to the Asia Financial crisis in 1997/98. The fiscal transfers from South Korea to North Korea and the migrants moving from North to South Korea are assumed to be the same as in the managed chaos case. 


\subsection{Simulation results}

\section{a. Status Quo}

We first generate a baseline of the model following the approach in McKibbin, Pearce, and Stegman (2007). We make assumption about the level of productivity in each sector in each country relative to the United States and the rate at which sectors catchup to the technical frontier of the United States. This generates a projection of productivity growth by sector by country out to 2100 . We combine this with the UN population projections (mid-term fertility) to generate the two exogenous drivers of economic growth in the model. We also make assumptions about tax rates, fiscal rules and monetary rules to generate a baseline projection of the global economy from 2015 to 2100 . We adjust the model so that the dynamic equations generate 2015 as the equilibrium of the model consistent with dynamic adjustment towards a steady state in the long distant future and consistent with firms and households having a degree of rational expectations. Capital accumulation and human capital are endogenously determined by the model thus the rate of economic growth is driven by population, productivity growth and sector specific capital accumulation which varies across sectors and across countries and across time.

In this status quo scenario, there are exogenous technological change, demographic changes and endogenous capital response to these changes. There are a large number of results for the global economy and the two Koreas. To give an idea of the growth implication in the status quo, Figure 5 shows the average productivity plus population assumptions built into the scenario for four of the countries in the model: USA, China, South Korea and North Korea. As can be seen from Figure 5, there is strong exogenous growth in China (mostly productivity), South Korea (productivity and demographics), and North Korea (mostly demographics). This is not the growth rates in the model but it summarizes the exogenous drivers of growth.

\section{b. Gradual Convergence and Reform}

In reading the results, it is important to note that all variables are expressed relative to the status quo. Thus a zero means the variable is equal to the status quo value of that variable. Variables are either: percentage deviation from the status quo (i.e. the level of GDP, investment; change in the growth rate relative to status quo; \% point deviation from status 
quo (i.e. for interest rates so $1 \%$ point would be an interest rate rising by $1 \%$ or 100 basis points) or percent of GDP deviation (e.g. trade balance and current account).

Figure 6 shows results for North Korea. It is clear that gradual reform that allows faster catchup of productivity plus transfers from South Korea raises the rate of economic growth (top right). Persistently higher economic growth of between $10 \%$ and $15 \%$ gradually increases the level of GDP (top left). The North Korean economy becomes $400 \%$ bigger by 2040. This is illustrative and very sensitive to the assumption of how quickly North Korea will catch up. A key part of the catchup is a rise in private investment which is shown in the middle left-hand chart. Note that because we have maintained a high degree of capital controls, the significant part of financing of the internal reforms and growth is funded by a fall in private consumption for a decade as resources are moved into more private investment. The transfers from South Korea are used to offset this consumption decline but there is still much weaker consumption than GDP growth for a decade from 2020 as resources are channeled into private investment. If it is assumed that capital markets will open or the government will borrow on global markets, then this internal financing can be avoided. The bottom two charts show the change in trade balance as a share of GDP and the change in real interest rates. The deterioration in the trade balance is the extent to which we allow capital to flow into North Korea. Thus there are significant capital controls which delay the desired accumulation of private capital.

With more capital and higher productivity, the average real wage rises in North Korea. With an imbalance between the demand for capital and available supply of capital, the shadow real interest rate in the economy rises but eventually falls as investment drives back down the marginal product of capital over a long period. The inflow of capital from overseas causes the North Korean Won to appreciate in real terms as well relative to the nominal US dollar. Once production rises in North Korea and trade expands, the relative price of North Korean goods begins to fall in the global economy.

A fiscal transfer from South to North (as a gift), is accounted for as a rise in the current account of North Korea. It enables some financing of the growth in North Korea just enough to offset the fall in private consumption. The transfer we assume is exogenous and based on the German experience.

The results for South Korea are shown in Figure 7. It is clear that under the assumptions used, the spillovers to South Korea are small relative to the South Korean economy. The 
transfer from South to North dominates the scenario. It implies a reduction in South Korea GDP which flows onto a reduction in investment and consumption since someone has to pay for the transfers to North Korea. Given current trade relations very little of the transfer finds its way back into demand for South Korean goods. This might be very different if the aid was targeted to buying capital goods from South Korea. This and many other policy issues can be explored in this model and will be analyzed in the next paper (Lee and McKibbin, 2017)..

\section{c. Managed Chaos in North Korea}

This scenario consists of a number of shocks as outlined above. The results for North Korea are contained in Figure 8.

The collapse in productivity shows up as an immediate fall in the North Korea GDP growth rate directly from the fall in productivity and destruction of the capital stock. It is important to note that the behavior in the first period is also affected by the knowledge in this scenario that eventually reform will be undertaken in future years. If the future reform was not expected, the collapse in North Korea would be more severe than in these charts. As reform begins 2 years after the collapse, real GDP growth rises in North Korea. The initial fiscal transfers also help buffer the decline in real GDP. Note that the migration from North to South Korea does limit the rise in real GDP because it reduces potential growth in North Korea. Also note that private consumption falls in the first year but rises more quickly than under the convergence scenario and there is a smaller rise in private investment due to the initial crisis.

Figure 9 contains the results for South Korea from managed chaos in North Korea. It is assumed that the only spillovers are through trade, some capital flows, and a flow of migrants from North South. In practice a number of other spillovers could be incorporated including those assumed in the final scenario below. The biggest effect in South Korea is the inflow of migrants from North Korea which raises potential output in South Korea. This is not surprising given that the size of the North Korean economy is small relative to South Korea but the number of people flowing from North to South is large relative to South Korea.

Real GDP, consumption and investment in South Korea gradually decline after the collapse of North Korea. This reflects the fiscal transfers from South to North which need to be paid out of either consumption or investment unless the South Korea government borrows on world markets to pay for the transfer (not considered in this paper but a plausible scenario). 
Note that the South Korean trade balance improves reflecting the flow of some capital out of South Korea into North Korea and also reflecting greater exports to North Korea. The South Korean current account worsens reflecting the payment of fiscal transfers to North Korea. Despite the negative effects on South Korea from the fiscal transfer in the short run, the inflow of migrants from North Korea gradually increases the labor supply in South Korea. This reduces real wages in South Korea but increases potential output. The size of gain in potential output should decrease if North Korean migrants have smaller human capital than that of the average South Korean worker and they need new education and training to adjust to the South Korea's free-market capitalism.

With private capital and government transfers flowing to North Korea and greater private investment to absorb the additional migrants in South Korea, private consumption needs to fall slightly to fund the fiscal transfers and investment increase. Without migration, the positive effects on GDP from North Korea are eliminated. Note that consumption falls by less in the short run without migration but falls by more in the long run without migration. This is because absorbing the workers in the short run is not needed and but losing the gain in potential output is more costly in the long run.

Also the financial effects on South Korea are dominated by the inflow of workers raising the marginal product of capital and pushing up interest rates. The real exchange rate depreciates due to the capital relocation within the two Koreas although the flow of migrants is the main cause of the depreciation

\section{d. Chaos in North Korea and Crisis of Confidence in South Korea}

Figure 10 presents the results for North Korea when there is instability in both Koreas due to the crisis in North Korea spreading more widely to the South. The more severe problems in the Korean peninsula show up in a large fall in GDP growth and a persistently slow recovery with weaker investment in North Korea. However, as reforms are implemented, North Korea shows strong investment and GDP growth over the mid- and long-term.

The results of this scenario are very different for South Korea. The loss of confidence in the South Korean policy makers leads to a capital outflow from South Korea, an increase in real interest rates and a collapse in private investment. South Korea enters recession and the South Korean Won depreciates by $14 \%$ in real effective terms. The falls in real GDP and real wages in South Korea are significant. 


\section{Concluding Remarks}

This paper has developed a new macroeconomic and sectoral database for North Korea for 2014. This data has then been used to develop a new model of the North and South Korean economies embedded in a widely used global economic model called the G-Cubed model.

The goal of the project is to develop a rigorous framework for analyzing scenarios for Korean unification. It is also to analyze a wide range of alternative policy responses in the two Koreas and the Asian region, focusing on institutional design issues such as monetary and fiscal frameworks, and spillovers to other countries in Asia and the Pacific. Given constraints on the amount of material that can be covered in a single paper we have focused here on developing the model and presenting a limited number of illustrative scenarios. This paper focuses on analyzing the effects of the unification process on North and South Korea. The spillovers to the neighboring economies will be the focus of a subsequent paper. Other papers will also cover the wide range of economic issues that emerge in attempting to model such a complex set of issues as the economics of Korean unification.

Despite the illustrative nature of this paper, a number of important insights emerge. First the relative scale of the two Koreas is very different to the experience of East and West Germany with the relative population difference much more similar in the case of the two Koreas but the differentials in economic activity orders of magnitude bigger than the two Germanys. The role of relative population is clear when we simulate migration flows between North and South Korea compared to the economic spillovers through trade and capital from North to South which are quite small. Despite the direct spillovers being small, there are important effects of the reform process on confidence in South Korea and the Korean Peninsula more generally which suggest potentially large costs if the process of unification is not handled well.

Another result is that resources need to be found to fund any unification process. This can be through North Korea giving up consumption in the short run to fund reform over time (considered in this paper), through fiscal transfers from South Korea (considered in this paper) or from opening the capital account to allow greater capital inflow (to be considered in a 
future paper). Each has a different implication for both Koreas. If South Korea is to fund fiscal transfers, then either these resources must come from reducing consumption and investment in South Korea (considered in this paper), higher taxes in South Korea (not considered) or borrowing from international markets (partially considered through capital inflows). Also migration flows from North to South have medium and long term implications for potential growth in both Koreas.

There are many more scenarios that the framework developed in this paper can be used to explore. These will be the focus of future papers. 


\section{References}

Bradford, Scott C. and Kerk L. Phillips (2005). A Dynamic General Equilibrium Model of Phased Korean Reunification. The Journal of the Korean Economy 6(1): 27-49.

Bradford, Scott C., Dong-Jin Kim and Kerk L. Phillips (2011). Potential Economic Reforms in North Korea: A Dynamic General Equilibrium Model. Journal of Economic Policy Reform 14(4): 321-332.

Cho, Young Gi (2015). Study on Monetary and Financial Policy of North Korea, (in Korean), KIF Working Paper.

Choi, Jiyoung (2014). Research on estimation of North Korean Input-Output tables. (in Korean), Understanding of North Korean Economy using Statistics 2014 Nov. Bank of Korea, pp. 125-156.

Choi, Jiyoung (2016). Estimation of Formal and Informal Sectors in Social Accounting Matrix for the North Korean Economy, (in Korean), BOK Working Paper No. 2016-14.

Funke, Michael and Holger Strulik (2005). Growth and Convergence in a Two-Region Model: The Hypothetical Case of Korean Unification. Journal of Asian Economics 16: 255-279.

Gagnon J., Masson, P. and W. McKibbin (1996). German Unification: What Have We Learned from Multi-Country Models Economic Modelling 13, no.4, pp 467-497.

Lee, Jong-Wha and Warwick McKibbin, (2017). The Economic Effects of German-Style Unification on Korea. In progress,

Lee, Won Kyung (2012). Exchange Rate of North Korea: Data and Trends, (in Korean), KDI North Korean Economy Review.

McKibbin, W. (1990). Some Global Macroeconomic Implications of German Unification Brookings Discussion Paper in International Economics \#81.

McKibbin W. D. Pearce and A. Stegman (2007) "Long Term Projections of Carbon Emissions" International Journal of Forecasting, vol 23, pp637-653

McKibbin, W., and P. Wilcoxen (2013). A Global Approach to Energy and the Environment:

The G-cubed Model in P. B. Dixon and D.W. Jorgenson, Editor(s), Handbook of Computable General Equilibrium Modeling, Elsevier, 2013, Volume 1, Chapter 17, North Holland, pp 995-1068.

Noland, Marcus, Sherman Robinson and Tao Wang (2000). Modeling Korean Unification. Journal of Comparative Economics 28: 400-421. 
Robinson, S., A. Cattaneo, and M. El-Said (2001). Updating and Estimating a Social Accounting Matrix Using Cross Entropy Methods. Economic Systems Research, Vol. 13, No. 1, pp.47-64.

Shin, Dong Cheon (2009). The estimation of a social accounting matrix for the North Korean economy and its application, (in Korean), Korea Review of Applied Economics Vol. 11, No. 1, pp.107-128.

St. Brown, Max, Seung Mo Choi and Hyung Seok Kim (2012). Korean Economic Integration: Prospects and Pitfalls. International Economic Journal 26: 471-485.

U.S. Department of State (2015). World Military Expenditures and Arms Transfers 2015, 33 ${ }^{\text {rd }}$ ed. 
Figure 1 Real GDP of North Korea (Trillion South Korean Won)

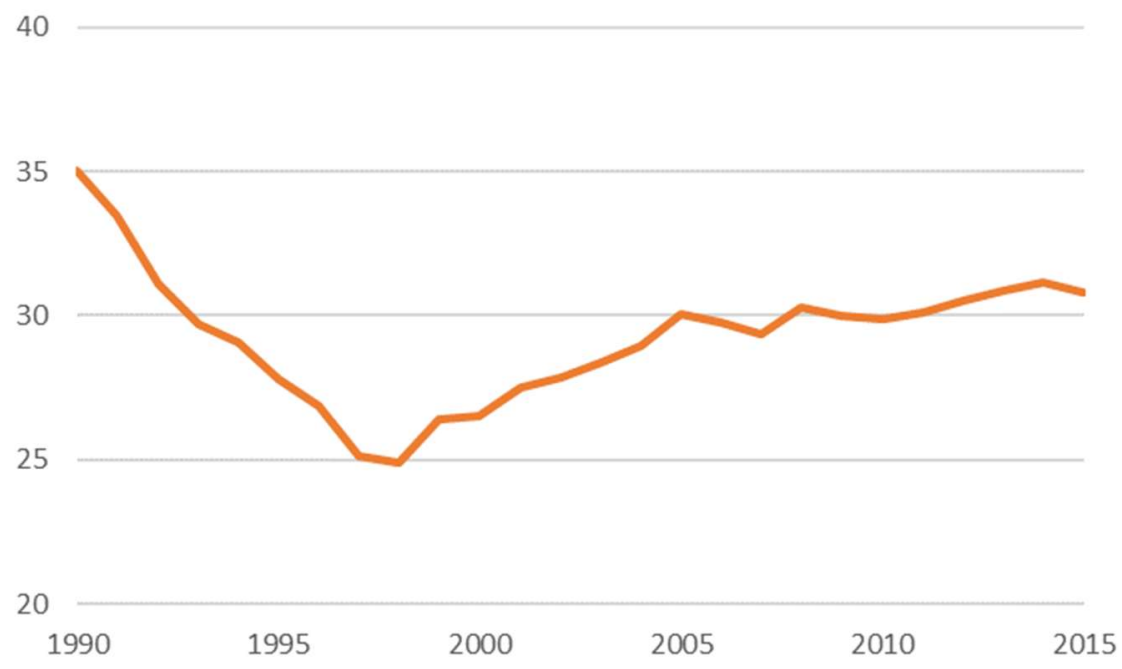

Source: Bank of Korea, Economic Statistics System 
Figure 2 Industrial Structure of North Korea (\%)

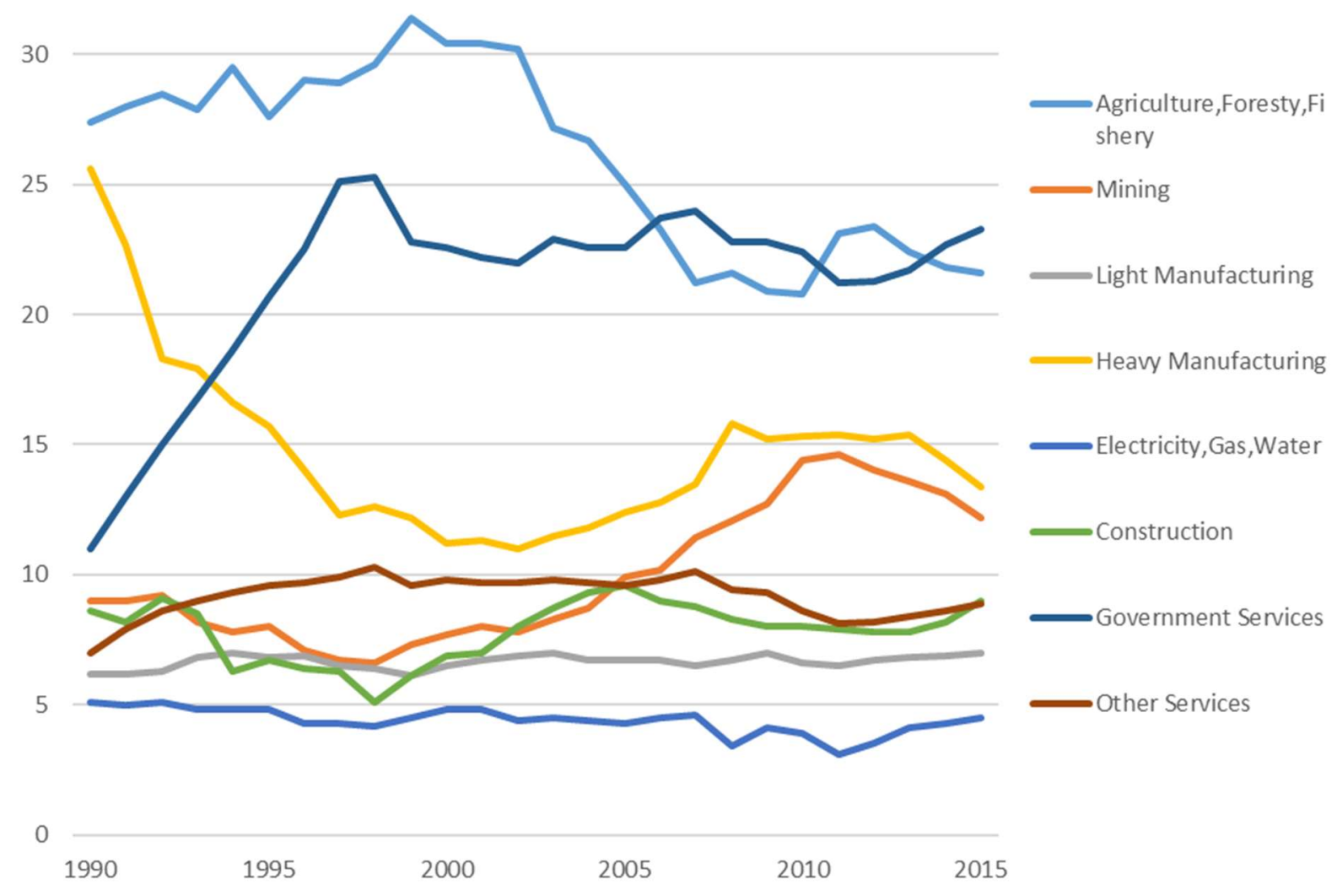

Source: Bank of Korea, Economic Statistics System 
Figure 3 Exports and imports of North Korea (Billion US dollar)

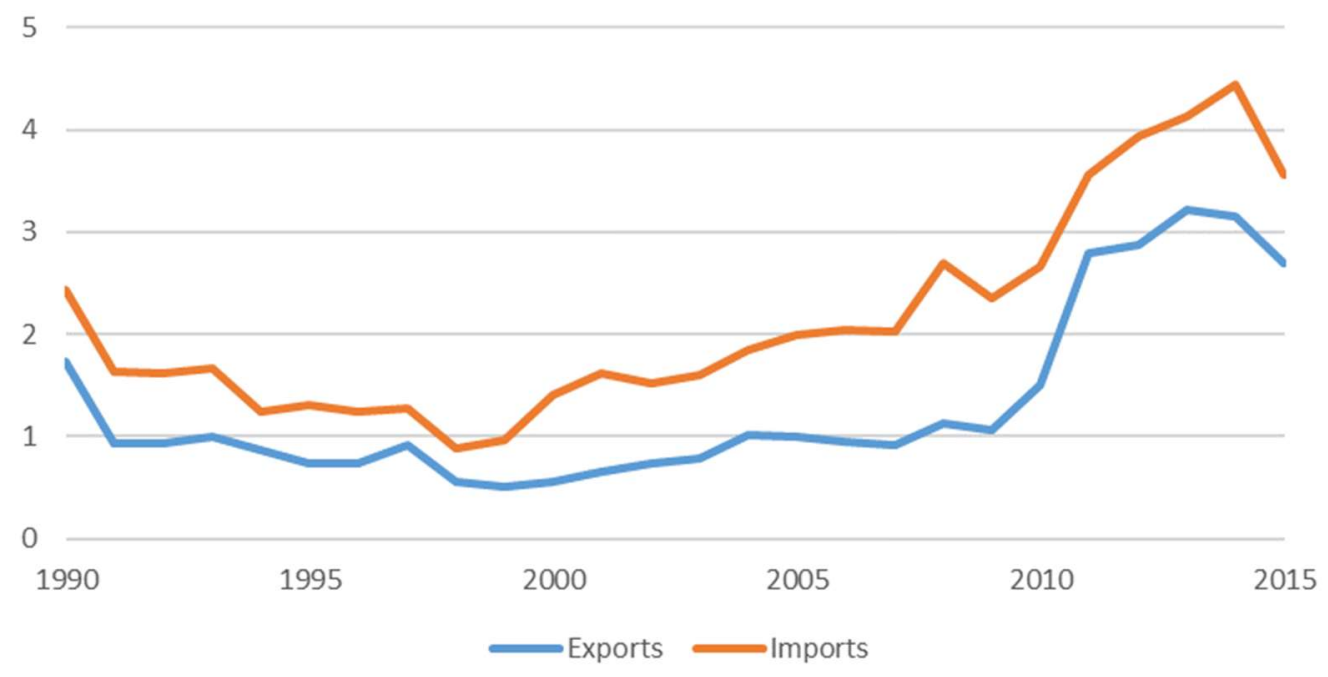

Source: Bank of Korea, Economic Statistics System 
Figure 4 Trade between South Korea and North Korea (Million US dollar)

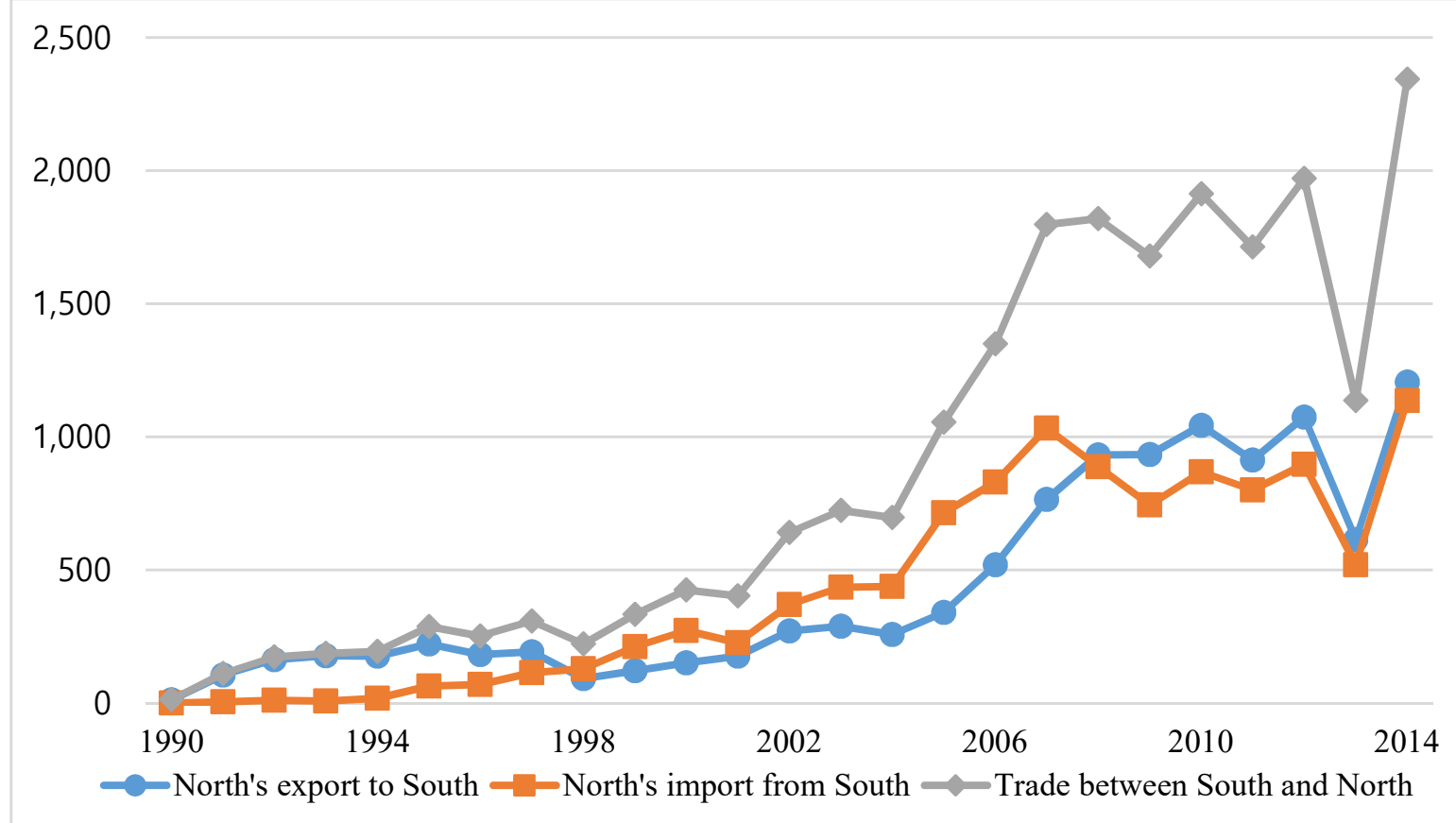

Source: Korea Statistical Office, North Korea Statistics. 
Figure 5: Population plus Labor productivity growth in Status Quo

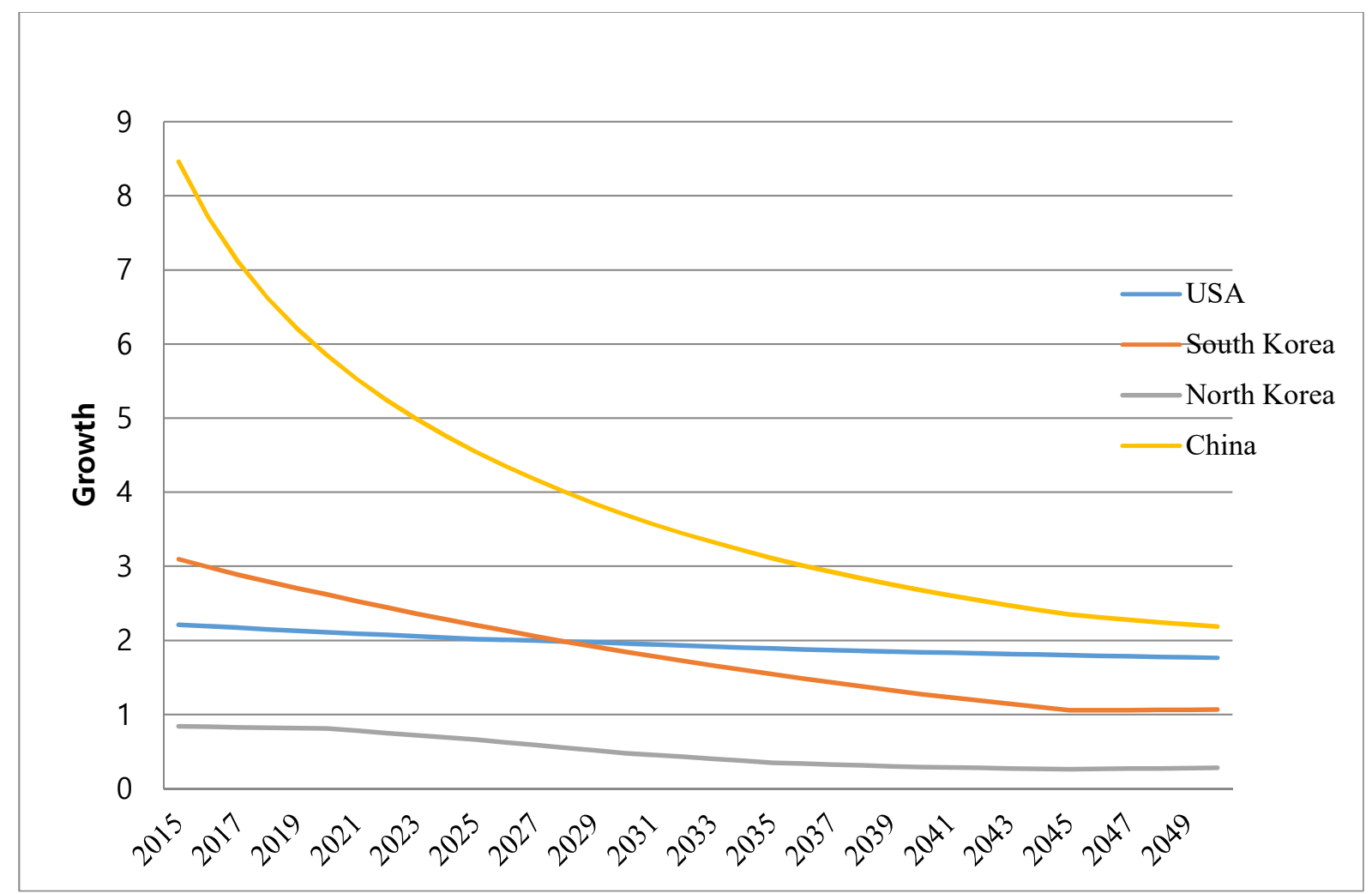


Figure 6: Convergence plus Transfer Scenarios - Results for North Korea

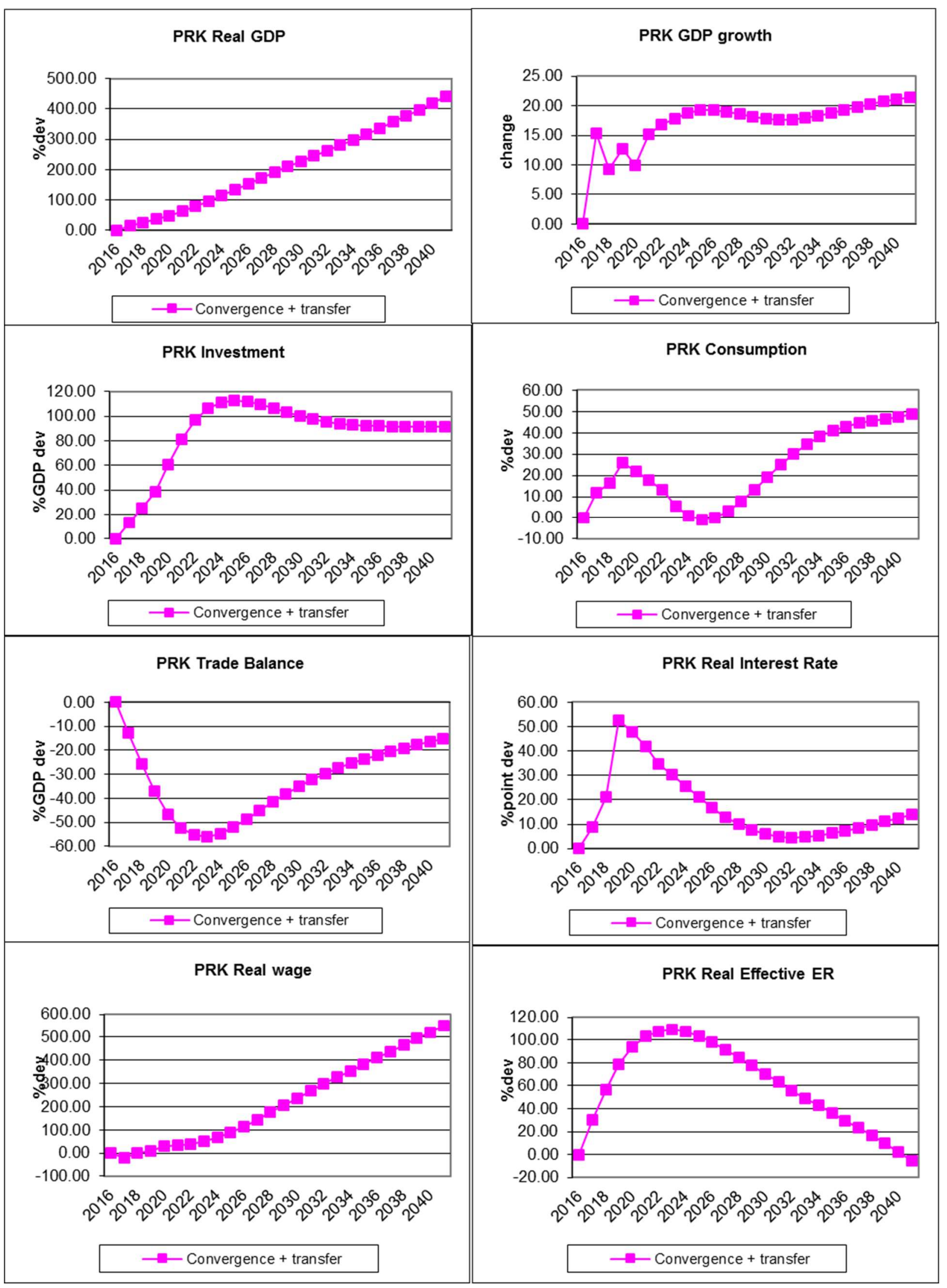


Fig 7: Convergence Scenarios - Results for South Korea

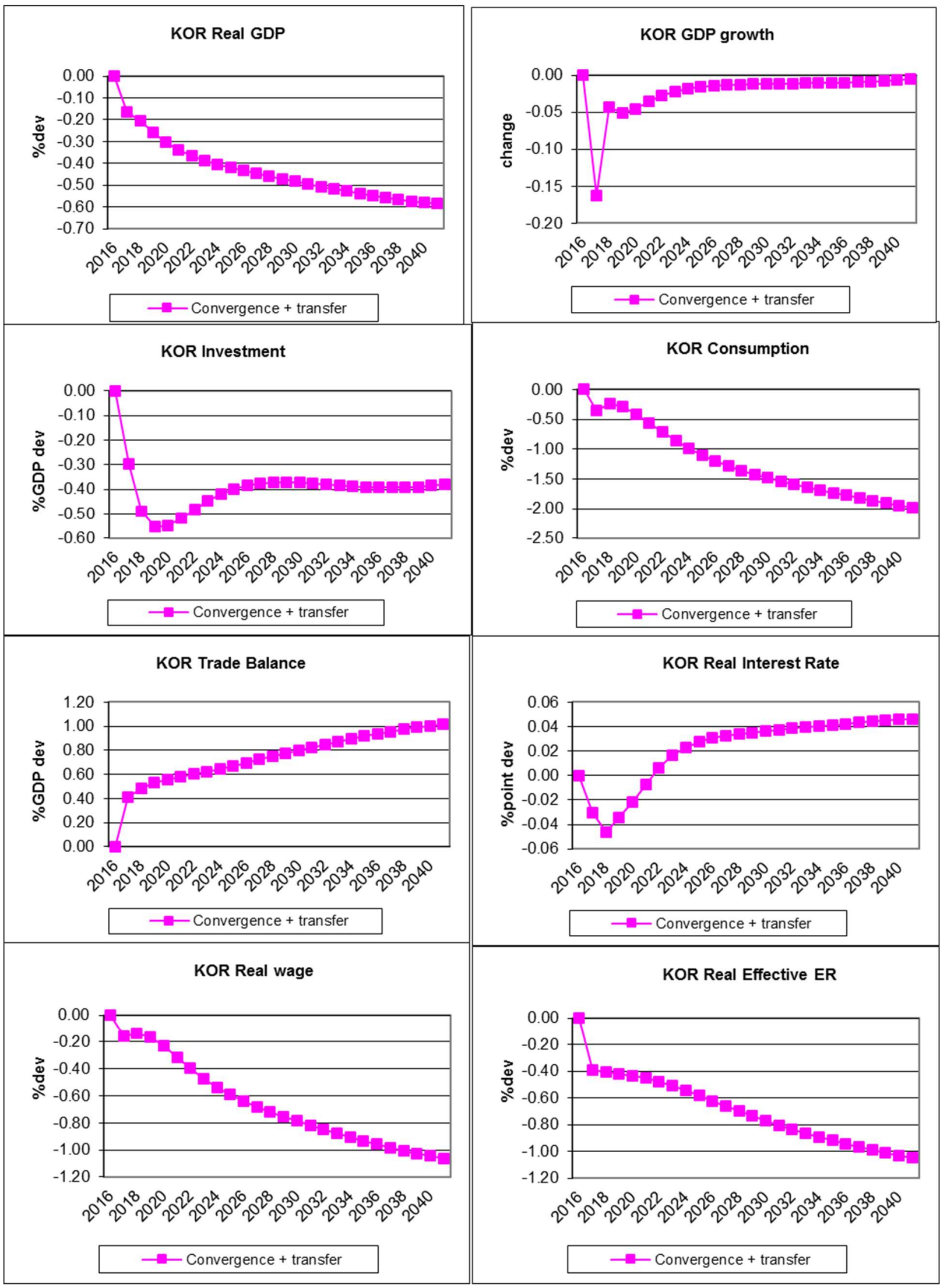


Figure 8: Managed Chaos in North Korea - Results for North Korea

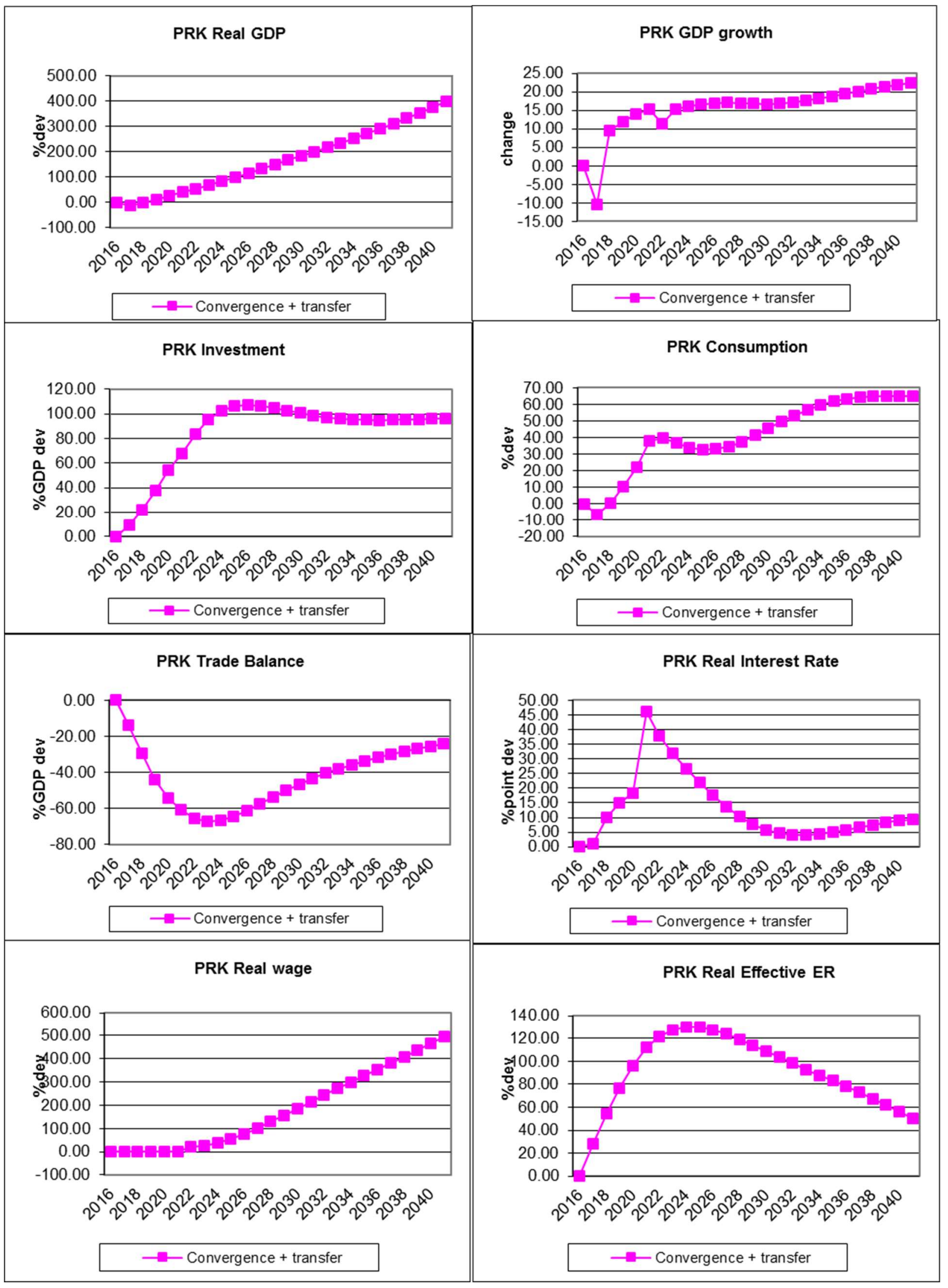


Figure 9: Managed Chaos in North Korea - Results for South Korea

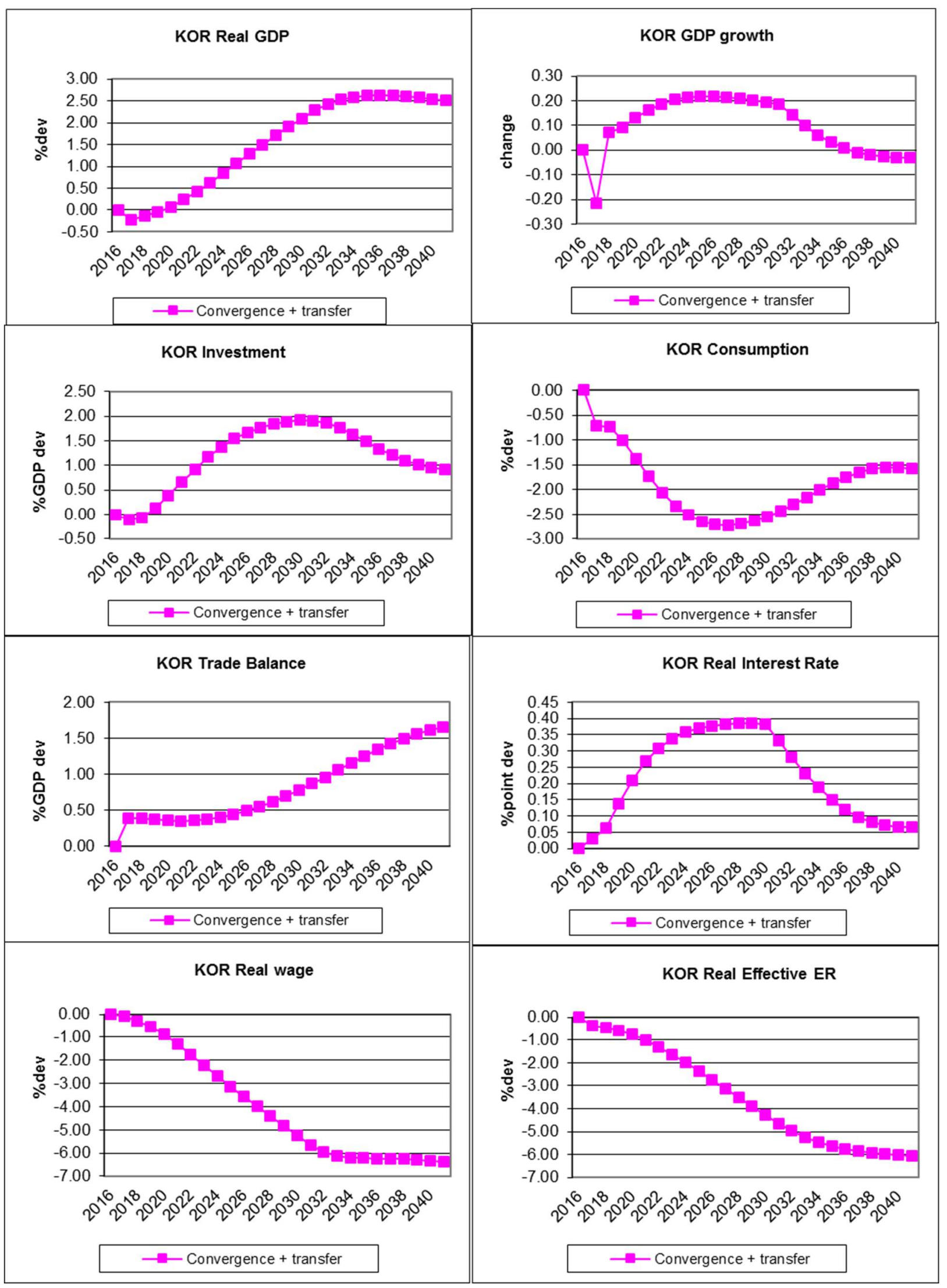


Figure 10: Chaos and Crisis in North and South Korea - Results for North Korea

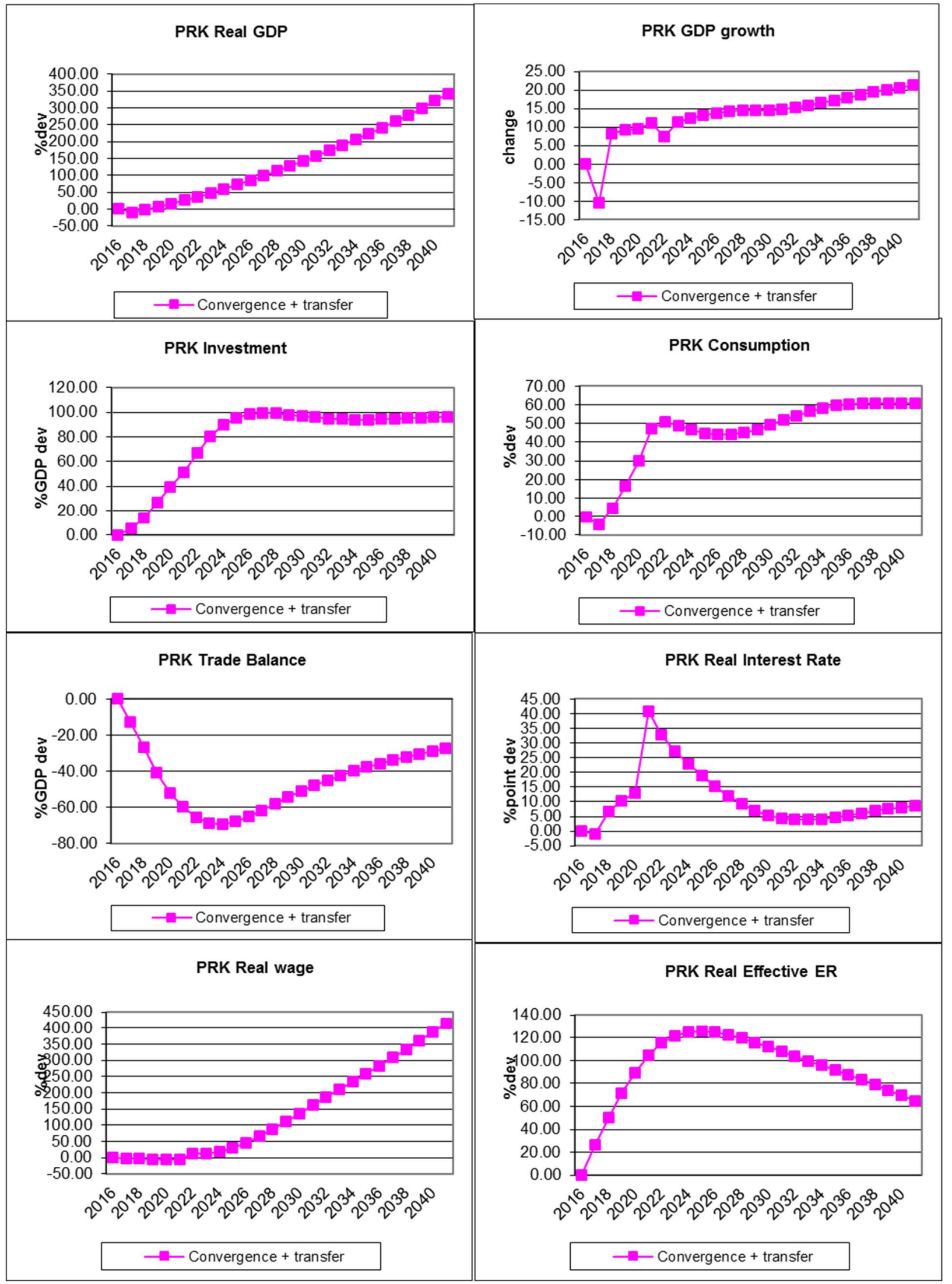


Figure 11: Chaos and Crisis in North and South Korea - Results for South Korea

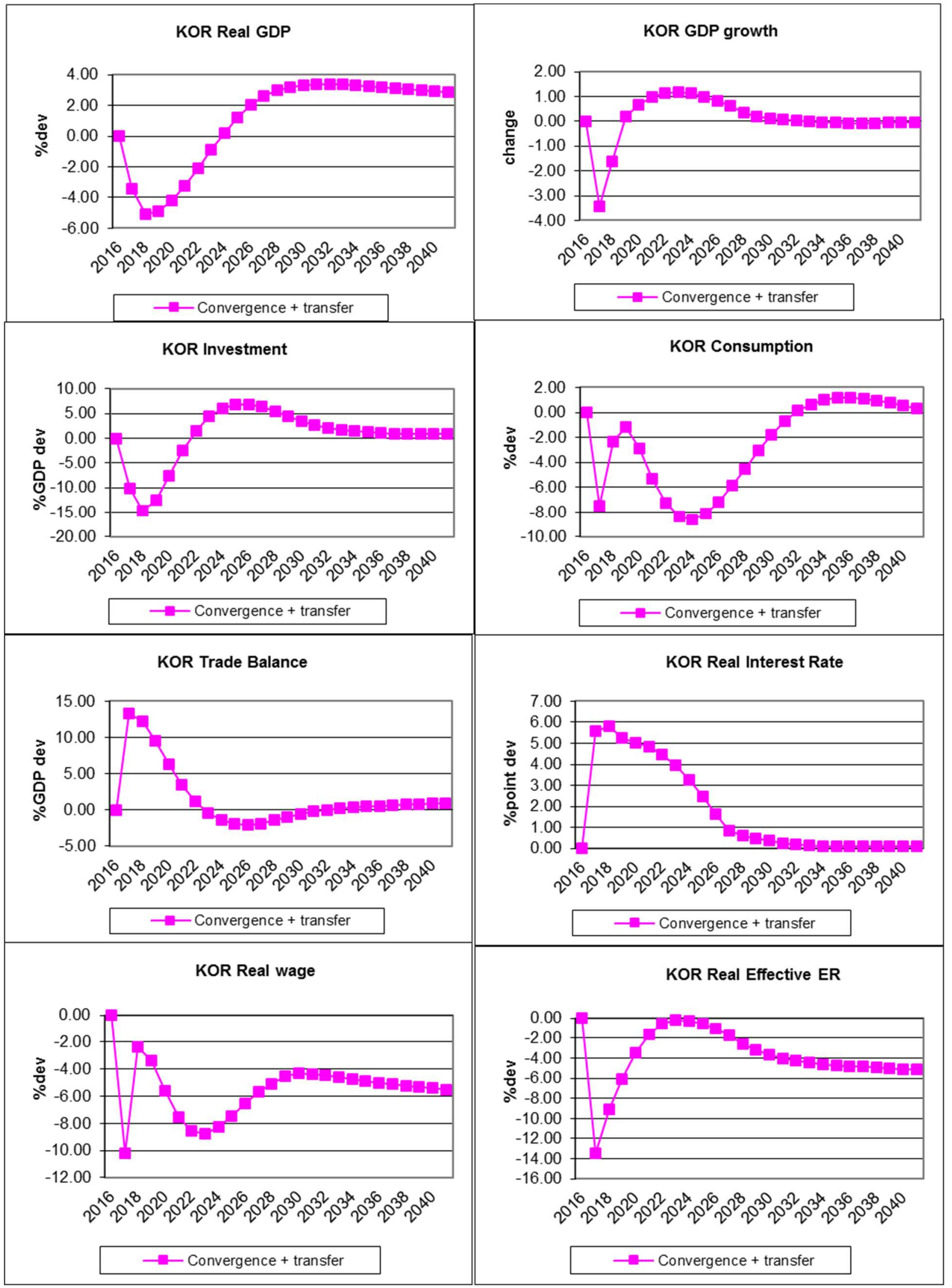


Table 1 North Korea's industrial employment and labor productivity in 2008

\begin{tabular}{|l|c|c|c|c|}
\hline Industry & $\begin{array}{c}\text { Number of } \\
\text { Workers }\end{array}$ & $\begin{array}{c}\text { Industrial Shares } \\
\text { in Employment } \\
(\%)\end{array}$ & $\begin{array}{c}\text { Real GDP } \\
\text { (billion WON) }\end{array}$ & $\begin{array}{c}\text { Labor } \\
\text { Productivity } \\
\text { (million WON) }\end{array}$ \\
\hline $\begin{array}{l}\text { Agriculture, Forestry and } \\
\text { Fishing }\end{array}$ & $4,386,895$ & 36.0 & $6,425.8$ & 1.46 \\
\hline Mining and Industry & $3,601,177$ & 29.6 & $11,133.4$ & 3.09 \\
\hline Mining and Quarrying & 718,195 & 5.9 & $4,346.2$ & 6.05 \\
\hline Manufacturing & $2,882,982$ & 23.7 & $6,776.2$ & 2.35 \\
\hline Light Industry & $1,323,366$ & 10.9 & $2,030.1$ & 1.53 \\
\hline Heavy Industry & $1,559,616$ & 12.8 & $4,744.8$ & 3.04 \\
\hline $\begin{array}{l}\text { Electricity, Gas and Water } \\
\text { Supply }\end{array}$ & 216,282 & 1.8 & $1,170.6$ & 5.41 \\
\hline Construction & 367,650 & 3.0 & $2,368.3$ & 6.44 \\
\hline Services & $3,612,716$ & 29.6 & $9,217.7$ & 2.55 \\
\hline Government & $2,405,770$ & 19.7 & $6,636.1$ & 2.76 \\
\hline Others & $1,206,946$ & 9.9 & $2,580.2$ & 2.14 \\
\hline Aggregate Economy & $12,184,720$ & 100 & $30,297.0$ & 2.49 \\
\hline
\end{tabular}

Source: Bank of Korea, Economic Statistics System (http://ecos.bok.or.kr) for real GDP and Korea Statistical Office, North Korea Statistics (http://kosis.kr/bukhan/index.jsp) for number of workers

Notes: North Korea's GDP is estimated in terms of South Korean WON. Light Industry includes food products, salt, beverage, tobacco, textile, wearing apparel, leather and related products, wood and of products of wood and cork, except furniture, paper and paper products, printing and reproduction of recorded media, furniture, living necessities products, other manufacturing, repair and installation of machinery and equipment. 
Table 2 South Korea's sectoral labor productivity in 2008

\begin{tabular}{|l|c|c|c|c|c|}
\hline \multirow{2}{*}{ Industry } & \multicolumn{3}{|c|}{ South Korea in 2008 } & (2) \\
\cline { 2 - 6 } & $\begin{array}{c}\text { Number } \\
\text { of } \\
\text { Workers } \\
\text { thousand } \\
\text { s) }\end{array}$ & $\begin{array}{c}\text { Industrial } \\
\text { Shares in } \\
\text { Employment } \\
(\%)\end{array}$ & $\begin{array}{c}\text { Real GDP } \\
\text { (billion } \\
\text { WON) }\end{array}$ & $\begin{array}{c}\text { Labor } \\
\text { Productivity } \\
\text { (million } \\
\text { WON) }\end{array}$ & $\begin{array}{c}\text { Ratio of } \\
\text { North Korean } \\
\text { labor } \\
\text { productivity } \\
\text { to South } \\
\text { Korean (\%) }\end{array}$ \\
\hline $\begin{array}{l}\text { Agriculture, forestry } \\
\text { and fishing }\end{array}$ & 1,686 & 8.6 & $28,646.6$ & 17.0 & 8.6 \\
\hline Mining and Industry & 3,986 & 3.9 & $313,517.8$ & 78.7 & 3.9 \\
\hline Mining and quarrying & 23 & 5.7 & $2,462.1$ & 107.0 & 5.7 \\
\hline Manufacturing & 3,963 & 3.0 & $311,055.7$ & 78.5 & 3.0 \\
\hline $\begin{array}{l}\text { Electricity, gas and } \\
\text { water supply }\end{array}$ & 156 & 3.7 & $23,063.9$ & 147.8 & 3.7 \\
\hline Construction & 1,812 & 19.6 & $59,503.8$ & 32.8 & 19.6 \\
\hline Services & 15,938 & 6.3 & $640,431.3$ & 40.2 & 6.3 \\
\hline Government services & 7,078 & 7.0 & $278,132.5$ & 39.3 & 7.0 \\
\hline Other services & 8,860 & 5.2 & $362,348.8$ & 40.9 & 5.2 \\
\hline Aggregate Economy & 23,577 & 5.5 & $1,065,183.3$ & 45.2 & 5.5 \\
\hline
\end{tabular}

Source: Bank of Korea, Economic Statistics System (http://ecos.bok.or.kr)

Note: Industry classification is fitted to North Korean case by the authors. The North Korean labor productivity level of each sector comes from Table 1 . . 
Table 3 Industrial Structure of North Korea and Vietnam in 2000, 2011 and 2014

\begin{tabular}{|l|c|c|c|c|c|c|}
\hline \multirow{2}{*}{ Industry } & \multicolumn{3}{|c|}{$\begin{array}{c}\text { North Korea } \\
\text { (\% of GDP) }\end{array}$} & \multicolumn{4}{c|}{ Vietnam } \\
& \multicolumn{2}{|c|}{$\%$ of Gross Value Added) } \\
\cline { 2 - 7 } & 2000 & 2011 & 2014 & 2000 & 2011 & 2014 \\
\hline Agriculture, hunting, forestry, fishing & 30.4 & 23.1 & 21.8 & 24.1 & 18.0 & 16.7 \\
\hline Mining, Manufacturing, Utilities & 30.2 & 39.6 & 38.7 & 32.6 & 35.2 & 35.9 \\
\hline \multicolumn{1}{|c|}{ Manufacturing } & 17.7 & 21.9 & 21.3 & 16.3 & 24.5 & 25.7 \\
\hline Construction & 6.9 & 7.9 & 8.2 & 5.3 & 6.6 & 6.6 \\
\hline Services & 32.5 & 29.4 & 31.3 & 37.4 & 40.5 & 41.3 \\
\hline
\end{tabular}

Source: BOK for North Korea, and UNSD for Vietnam 
Table 4 Share in total trade by industry of North Korea, South Korea and Vietnam, selected years $(\%)$

\begin{tabular}{|l|c|c|c|c|}
\hline \multirow{2}{*}{ Industry } & North Korea & Vietnam & \multicolumn{2}{c|}{ South Korea } \\
\cline { 2 - 5 } & 2014 & 2011 & 1970 & 1975 \\
\hline Agriculture & 9.9 & 4.7 & 21.9 & 17.8 \\
\hline Manufacturing & 65.4 & 68.6 & 64.5 & 63.2 \\
\hline Services & 0.0 & 20.8 & 7.4 & 8.1 \\
\hline
\end{tabular}

Source: KOTRA(North Korea), OECD STAN database(Vietnam), Bank of Korea(South Korea) 
Table 5 Input coefficient matrix of North Korea in 2014

\begin{tabular}{|c|c|c|c|c|c|c|c|c|c|c|c|}
\hline & Energy & Mining & Agri. & $\begin{array}{l}\text { Durable } \\
\text { Manufacturing }\end{array}$ & $\begin{array}{l}\text { Non-Durable } \\
\text { Manufacturing }\end{array}$ & Services & $\mathrm{C}$ & I & G & $X$ & $\mathrm{M}$ \\
\hline Energy & 0.0477 & 0.0046 & 0.0039 & 0.0036 & 0.0094 & 0.0144 & 0.0350 & 0.0443 & 0.0002 & 0.2701 & 0.1348 \\
\hline Mining & 0.1443 & 0.1713 & 0.0043 & 0.0577 & 0.0771 & 0.0103 & 0.0697 & 0.0624 & 0.0066 & 0.0939 & 0.0203 \\
\hline Agri. & 0.0002 & 0.0001 & 0.2930 & 0.0078 & 0.2149 & 0.0660 & 0.3465 & 0.0862 & 0.0271 & 0.0679 & 0.1229 \\
\hline $\begin{array}{l}\text { Durable } \\
\text { Manufacturing }\end{array}$ & 0.0393 & 0.0724 & 0.0131 & 0.6238 & 0.0356 & 0.0852 & 0.1233 & 0.6971 & 0.0394 & 0.2100 & 0.3551 \\
\hline $\begin{array}{l}\text { Non-Durable } \\
\text { Manufacturing }\end{array}$ & 0.0240 & 0.0080 & 0.1034 & 0.0930 & 0.3659 & 0.1106 & 0.1286 & 0.0104 & 0.0109 & 0.3580 & 0.3668 \\
\hline Services & 0.0546 & 0.0501 & 0.0551 & 0.0543 & 0.1114 & 0.1440 & 0.2970 & 0.0997 & 0.9158 & 0 & 0 \\
\hline Labor & 0.3276 & 0.3296 & 0.1583 & 0.0867 & 0.0844 & 0.2900 & & & & & \\
\hline Capital & 0.3623 & 0.3639 & 0.3690 & 0.0731 & 0.1013 & 0.2794 & & & & & \\
\hline Sum & 1 & 1 & 1 & 1 & 1 & 1 & 1 & 1 & 1 & 1 & 1 \\
\hline
\end{tabular}

Note: Author's calculation. 
Table 6 New Input-Output table of North Korea in 2014 (millions, USD)

\begin{tabular}{|c|c|c|c|c|c|c|c|c|c|c|c|c|c|c|}
\hline & Energy & Mining & Agriculture & $\begin{array}{l}\text { Durable } \\
\text { Manufacturing }\end{array}$ & $\begin{array}{l}\text { Non-Durable } \\
\text { Manufacturing }\end{array}$ & Services & $\begin{array}{l}\text { Total } \\
\text { Intermediate } \\
\text { Demand }\end{array}$ & $\mathrm{C}$ & I & G & $\mathrm{X}$ & $\begin{array}{l}\text { Total } \\
\text { Final } \\
\text { Demand } \\
\end{array}$ & M & $\begin{array}{l}\text { Total } \\
\text { Output }\end{array}$ \\
\hline Energy & 103.1 & 30.4 & 57.3 & 114.1 & 122.7 & 278.3 & 705.8 & 519.9 & 507.4 & 1.7 & 1180.7 & 2209.7 & -752.8 & 2162.7 \\
\hline Mining & 312.0 & 1137.7 & 62.3 & 1826.4 & 1010.8 & 198.2 & 4547.4 & 1036.1 & 714.6 & 46.7 & 410.4 & 2207.7 & -113.5 & 6641.6 \\
\hline Agriculture & 0.4 & 0.7 & 4260.9 & 247.9 & 2816.6 & 1273.3 & 8599.8 & 5152.4 & 987.0 & 192.9 & 296.7 & 6629.1 & -686.3 & 14542.6 \\
\hline $\begin{array}{l}\text { Durable } \\
\text { Manufacturing }\end{array}$ & 85.0 & 480.8 & 190.6 & 19728.7 & 466.7 & 1642.6 & 22594.5 & 1833.5 & 7984.3 & 280.8 & 918.1 & 11016.7 & -1982.3 & 31629.0 \\
\hline $\begin{array}{l}\text { Non-Durable } \\
\text { Manufacturing }\end{array}$ & 51.9 & 53.2 & 1503.2 & 2941.1 & 4795.7 & 2133.8 & 11478.8 & 1913.0 & 119.3 & 77.3 & 1564.9 & 3674.5 & -2047.9 & 13105.4 \\
\hline Services & 118.2 & 332.5 & 800.6 & 1718.4 & 1459.5 & 2776.3 & 7205.5 & 4416.6 & 1141.6 & 6520.6 & 0.0 & 12078.8 & 0.0 & 19284.2 \\
\hline $\begin{array}{l}\text { Total } \\
\text { Intermediate } \\
\text { Input }\end{array}$ & 670.5 & 2035.3 & 6875.0 & 26576.4 & 10672.0 & 8302.6 & 55131.8 & & & & & & & \\
\hline Labor & 708.6 & 2189.3 & 2301.7 & 2741.5 & 1105.5 & 5593.1 & 14639.7 & & & & & & & \\
\hline capital & 783.6 & 2417.1 & 5365.8 & 2311.0 & 1327.9 & 5388.6 & 17594.1 & & & & & & & \\
\hline Value Added & 1492.2 & 4606.4 & 7667.6 & 5052.5 & 2433.4 & 10981.7 & 32233.8 & & & & & & & \\
\hline Total Input & 2162.7 & 6641.6 & 14542.6 & 31629.0 & 13105.4 & 19284.3 & 87365.6 & 14871.4 & 11454.2 & 7120.0 & 4370.9 & 37816.5 & -5582.7 & 87365.6 \\
\hline
\end{tabular}

Note: Author's calculation. 
Table 7 Economies and regions in the G-Cubed model

\begin{tabular}{l|l}
\hline United States & North Korea (PRK) \\
Japan & China \\
Australia & India \\
Europe & Eastern Europe the former Soviet Union \\
Republic of Korea (KOR) & Oil Exporting Developing Countries \\
Rest of OECD & Rest of the World \\
\hline
\end{tabular}

